\title{
California's Legislature Faces the Small Loan Problem
}

$P_{\text {Rospects of settling a question with which California lawmakers }}$ regulation of the small loan business-appeared to be rather bright as the legislators reassembled early in March following the constitutional recess. Fifteen bills ${ }^{2}$ embodying various philosophies of small loan regulation have been introduced and there appears to be a growing insistence on the part of both the legal profession ${ }^{3}$ and the public ${ }^{4}$ that a legal maximum be fixed on the charges which "personal property brokers and brokers" under the Personal Property Brokers Act $^{5}$ and unsecured lenders ${ }^{6}$ throughout the state can require of

1 This excludes, of course, the Pawnbrokers' Act of April 17, 1861 (Cal. Stats. 1861, p. 184), which served as basis for Penal Code sections 338-343 when the codes were adopted in 1872. Modern consideration of the small loan problem as such, however, began in 1905 with adoption of two statutes (Cal. Stats. 1905, p. 422 and ibid., p. 711). Pawnbrokers lend on the security of articles pledged with them. Personal property brokers lend on the security of chattel mortgages, wage assignments, etc. See definitions, note 5, infra.

2 Actually 19 bills, but in four instances identical bills were introduced in both houses of the legislature. This figure does not include bills applying to types of loan agencies other than personal property brokers.

${ }^{3}$ See Loan Shark Activities in California, published by the Legal Aid Society of San Francisco, Dec. 15, 1938, and prepared by R. H. Cross, chairman, Percy J. Creede and John Paul Jennings.

"The attention given "Ioan shark" stories in the San Francisco News, Los Angeles Times, Los Angeles Herald and Express, Los Angeles Evenirtg News and other newspapers is indicative of this.

5It is necessary to distinguish between a "personal property broker" and a "broker" as defined in and subject to regulation under the Personal Property Brokers Act, Cal. Stats. 1933, p. 1496.

Sec. 2-(2) defines the term "personal property broker" as used in the Act as embracing "all who are engaged in the business of lending money and taking in the name of the lender, or in any other name, in whole or in part, as security for such loan, any contract or obligation involving the forfeiture of rights in or to personal property, the use and possession of which property is retained by other than the mortgagee or lender, or all who are engaged in the business of lending money and taking in the name of the lender, or in any other name, in whole or in part as security for such loan, any lien on, assignment of, or power of attorney relative to wages, salary, earnings, income or commission."

Sec. 2-(3) states that the term "broker" as used in the Act "shall be deemed to include all who are engaged in the business as agent of the borrower, or otherwise, in negotiating, for a compensation, a loan to be made by a personal property broker."

The Personal Property Brokers Act sets up a licensing system under the administration of the Corporation Commissioner, but he is without authority to limit the "interest" and "charges" of the licensees, because "personal property brokers" and 


\section{borrowers. ${ }^{7}$}

The Legal Aid Society of San Francisco has taken the lead in bringing the weight of the legal profession to bear on the question. After a lengthy study of possible remedies the Society drafted two bills, largely based on the sixth draft of the Uniforn Small Loan Act of the Russell Sage Foundation ${ }^{8}$ and intended to apply to both the personal property broker and the unsecured lender. Both bills have been introduced at the legislature. ${ }^{9}$

Under existing statutes a personal property broker ${ }^{10}$ operates without legal limit of any kind with respect to charges. California and Nevada are the only states which do not impose some such restriction. ${ }^{11}$

The unsecured lender, as the name implies, makes loans merely on the signature and agreement of the borrower to repay. He has at nost a co-signor's signature upon which to rely in enforcing his obligation. ${ }^{12}$ The Usury Amendment ${ }^{13}$ limits the interest such a lender can collect to ten per cent per annum, but there is no legal limitation on brokerage fees and similar charges. The brokerage system in Califorma is so developed that in fact the restrictions of

\footnotetext{
"brokers" are exempt from the restrictions on maximum rates of interest as prescribed in section 22 of article XX of the California constitution.

'See infra note 12.

7 The small loan field, of course, includes loans made by tbe personal loan departments of banks, industrial or Morris plan banks, building and loan associations, credit unions, co-operative agricultural marketing organizations, pawnbrokers, and bona fide installment sales contractors as well as tbe loans made by personal property brokers and unsecured money lenders. Legislation, particularly as to charges, is already operative for most of these types of lenders, however, and criticism of the present situation is largely concentrated on the activities of the personal property brokers, unsecured lenders, and the brokers who negotiate between them and borrowers.

8 The Russell Sage Foundation, the nation's outstanding private organization in the field of social welfare research, after a seven-year study of the small loan problem, published the first draft of its Uniform Act in 1916. As experience in actual operation has revealed the need for changes and refinements the Act bas been altered and a new draft prepared. The sixth and latest draft appeared in 1935. A seventh draft is being prepared, but it will contain no material changes from the sixth draft. Letter from Rolf Nugent, Director, Department of Consumer Credit Studies, Russell Sage Foundation, New York City, dated Feb. 14, 1939.

0 Senate Bills 1066, 1125, and Assembly Bills 1192, 1193.

10 Supra note 5.

11 See Thodras, Small Loan Legislation (Legislative Problems, No. 1, Bureau of Public Administration of the Umiversity of California, 1939).

12 A co-signor is a "surety" and the inference migbt be drawn that the obligation is not unsecured. It is not one of the types of security, bowever, upon which the personal property broker can lend, so it is generally classed in the trade as an unsecured obligation.

13 CAI. Const. art. XX, § 22, adopted Nov. 6, 1934.
} 
the Usury Amendment, applying as they do only to the unsecured lender, do not prevent the broker who usually negotiates the loan, and who may be the front for the lender, from making any charge which the traffic will bear.

The result of such a state of affairs is a familiar story to most California attorneys. Complaints from clients about "loan shark" activities are heard all too frequently in legal offices. For instance, an Oakland man borrowed $\$ 50$ and repaid $\$ 180$ over a period of 18 months, paying $\$ 5$ every two weeks, but in the end he still owed the original $\$ 50$. Advertisements printed openly in the Los Angeles newspapers set forth "special low rates" which may amount to 250 per cent and more per year. However much such rates may violate a moral definition of usury, lenders can maintain, with truth, that they are operating within the law.

These introductory remarks raise several questions. Why is regulation of the small loan business, particularly as regards personal property brokers and unsecured lenders, considered necessary? If regulation is needed, why should the interest rate-or charges-be any different from that allowed on other types of loans? If the situation is as bad as the foregoing remarks make it appear why hasn't something been done about it before now? What are the basic differences in the small loan bills before the legislature? What constitutional questions would be involved in enacting a valid and effective regulatory measure in California? Does experience in other states suggest some course of action for California? What would be the effect here, in the light of California court decisions, if the Uniform Small Loan Act already operating in twenty-five states were adopted?

The remainder of this article will be devoted to an attempt to answer these questions.

\section{WHY REGULATION OF THE SMALI LOAN BUSINESS IS NECESSARY}

Exact figures are not available, but it is estimated that personal finance companies, corresponding to personal property brokers and unsecured lenders in California, loan from $\$ 350,000,000$ to $\$ 500$,000,000 annually in the United States, an amount larger than that loaned by any other agency in the field. ${ }^{14}$ In view of the absence of regulation of rates in California and the consequent encouragement

14. Neifedd, The Personal Finance Bustness (1933) 138; Robinson and Stearns, Ten Thousand Smaid Loans (1930) 14; Fowler, The Licensed Lender (1938) 196 Annars 130; Grobben, Volume and Classification of Consumer Loans, ibid. 74. 
for the opening of loan offices, it would appear logical that at least a proportional share of the nation-wide business is done in this state.

A primary requisite to the consideration of this subject is recognition that small loans have an important and well established position in the country's credit structure. By means of such loans, individuals in that large segment of population between the poverty line and the commercial bank window have access to credit, even though they can pledge only their prospects, character, furniture or automobile.

Customers of these loan offices are, for the most part, persons capable of earning a modest living but without sufficient resources to meet, unaided, the additional expense involved in purchasing furniture, or an automobile, or meeting bills created by illness, unemployment or other emergency. ${ }^{15}$

These borrowers, despite their numbers, constitute a rather helpless group because of their ignorance, partially the result of carelessness, of the true nature of their obligations under the loan, and ignorance of their legal rights and remedies. Further, these borrowers are placed at the mercy of lenders in that they are frequently in such need of money that they are willing to pay any price to get it. There is also the fact that certain lenders have developed deceptive procedures to a point of near perfection, procedures involving such things as "ballooning," a system whereby the contract calls for a large final payment which the borrower will probably be unable to meet on the due date. ${ }^{16}$ Thus he is in the need of refinancing the loan with the attendant loading charges and brokerage fees. This process may well continue indefinitely.

Experience indicates that, in the absence of proper regulation, the small loan business attracts unscrupulous men willing to take full advantage of the necessities and ignorance of borrowers. In the states where the problem appears to have been best solved, lenders in the small loan busimess are exempted from operation of the general usury statutes providing they take out a state license and conduct their business under state regulation. ${ }^{17}$ Penalties are provided for violations of these regulations. ${ }^{18}$

10 NEnrerd, op. cit. supra note 14, 164; RoBINSON and STEARNs, op. cit. supra note 14; Neifeld, What Consumer Credit Is (1938) 196 Anwars 63, 67.

16 See Liebelt v. Carney (1931) 213 Cal. 250, 2 P. (2d) 144, (1932) 78 A. L. R. 405, reli'g den., Aug. 27, 1931.

17 These regulations require, among other things, that the lenders post bond, mamtain books open to the inspection of state officers, and observe definite requirements in 


\section{THE PROBLEM OF FIXING SMAII IOAN CHARGES}

The most difficult problem of small loan regulation is that of fixing a rate which will give borrowers a maximum of protection and still attract a flow of capital to the loan business sufficient to meet the demand for loans. It must be realized from the start that criteria for rate making are social as much as financial.

The freedom of contract theory, that the forces of supply and demand in the open market would effectively regulate interest charges, has proved inadequate in the small loan field, partly because the different agencies usually require different types of security. More important limitations upon the free operation of competitive forces, however, are the ignorance and poor bargaining powers of the loan applicants and the use by the lenders of devices to camouflage the loan price structure. Many evils in the present situation in California arise from the fact that under the Personal Property Brokers Act the rule of freedom of contract prevails in the small loan field.

Thirteen states attempt to regulate the small loan business under usury statutes fixing a maximum annual interest rate of from 6 to 12 per cent, ${ }^{19}$ but experience seems to indicate that such a policy is unsatisfactory, for it prevents legitimate lending in the small loan field. Small loan agencies comparable to personal property brokers or unsecured lenders cannot make a profit on loans which return no more than one per cent per month, where such return must cover all expenses connected with making and collecting the loan. It costs proportionately more to investigate a prospective borrower, lend him $\$ 100$ and collect it in installments, than it does to make a regular commercial bank loan of $\$ 5000$. The security offered by small loan

the making and payment of loans, including delivery to the borrower of a printed copy of provisions of the Act relating to charges, a plain and complete statement of charges, provision for repayment in advance of the due date at any tine and in any amount, release and return of any mortgage, note or assignment on repayment and display of a full schedule of charges at the place of business.

18 Among the acts which are made misdemeanors are operating without a license, failing to keep proper books, false advertising, taking liens on real estate, doing other business in the office where loans are made, taking a confession of judgment or power of attorney, overcharging, splitting loans, collecting interest in advance and failing to observe the requirements for making and payment of loans.

10 Montana, New Mexico, South Dakota, Wyoming and Washington bave a 12 per cent usury law; Arkansas, Idalio, Kansas, North Dakota, Oklaboma and Texas have 10 per cent laws; while South Carolina allows a maximum of 8 per cent and North Carolina only 6 per cent. See Robinson and Nugent, Regutation of the SMall LoaN BusINEsS (1935) 67-69. 
customers, moreover, is such that the personal finance company's risk of loss is greater than that of a bank which makes a productive loan. Loan company profits must come from lending cash capital or money borrowed at commercial rates, while banks and similar establishments need only a broker's profit, for they lend the money of depositors who are paid little or no interest. The result is that the ordinary usury rate, if the law is so phrased that this "interest" must include all charges paid by the borrower, makes it impossible to operate a small loan business at a profit-but does not eliminate the demand nor the need for such loans.

Semi-philanthropic remedial loan societies ${ }^{20}$ and credit unions ${ }^{21}$ have proved inadequate to meet the major portion of the small loan needs. It appears, therefore, that, short of the actual establishment of small loan offices by some governmental agency, ${ }^{22}$ commercial agencies must be depended upon to meet the bulk of the small loan demands and it is in the public interest that a rate structure be provided which will protect the borrower and still allow a profit sufficient to attract the necessary capital.

In the past twenty years such special rate structures have been adopted in many states. ${ }^{23}$ These laws, based upon the Uniform Small Loan Act, have attempted to limit "charges" rather than "interest," for the general policy has been to make the maximum permissive rate all-inclusive, covering both pure interest and the costs of completing the transaction. The statutes provide that "charges" be computed on a monthly basis and that they apply only to the unpaid principal balance.

On the basis of experience over the nation with varying rates for small loans this tentative theory for rate making has been postulated:

20 Sufficient capital to meet the loan demand was not attracted to these societies and facilities could not be made available to the poorer type of borrower. See GaLIERT, Hirborn and May, SMaLl Loan Legislation (1932) 12-15.

21 The 6500 credit unions thus far organized are available to only a small fraction of the borrowers of small loans in the United States. See Orchard, Coöperative Con sumer Credit (1938) 196 ANNAIs 155.

22 In re Washer (1927) 200 Cal. 598, 606, 254 Pac. 951, 954: “. . In the operation of many city governments, they are, by reason of section 6 of article XI of the constitution, free from the operation of general laws at all." This raises the interesting implication that, should they so choose, cities might go into the lending business in California and be outside the operation of the usury law.

23 Including Connecticut, Florida, Illinois, Indiana, Iowa, Kentucky, Louisiana, Maine, Maryland, Michigan, Missouri, New York, Oregon, Pennsylvania, Rhode Island, Verınont, Virginia, West Virginia and Wisconsin. See Hubacher, Annotations on SMratr LoaN Laws (1938) 210. 
"The range of rates which attract commercial capital to the business of lending money in sums of $\$ 300$ or less begins with approximately $21 / 2$ per cent a month. As the maximum rate is increased beyond this point, lower strata of borrowers to whom loans cannot be made profitably at a lower maximum become eligible for loans from the licensed lender, and competition for the higher strata of borrowers tends to decrease the rate of charge for larger or better secured loans."24

Small loan experts of the Russell Sage Foundation recommend a maximum rate of $31 / 2$ per cent per month on the first $\$ 100$ of any loan balance, but admit this rate might not apply to any particular state. $^{25}$ The available evidence, however, appears to indicate that $2 \pi / 2$ per cent per month applying to all contracts is the lowest maximum rate which would be effective under the most favorable conditions and that this rate is too low to be effective in most states.

In addition to the strictly financial aspects of regulating small loan charges, several social factors should be taken into consideration: First, an extremely low rate such as one per cent per month, if this is to cover all costs of a loan, will virtually eliminate legal lending in small loans. Strict enforcement of such a law will make it impossible for most of the present customers of personal property brokers and unsecured lenders to obtain loans. Nothing short of a complete change in our economic system, however, will eliminate the demand for such loans and illegal loans will be made extremely costly because of the risk and social stigma attached to the business. Second, a moderately low rate will attract a limited flow of capital into the small loan field and tend to make possible less risky personal loans, but the possibility of illegal lending to applicants whose security will not warrant a legal loan will continue to be quite great. Third, a rate between $21 / 2$ and $31 / 2$ per cent per month probably will make it possible for small loan agencies to accommodate the same types of borrowers who are using their facilities at present in California and will prevent "loan shark" abuses. ${ }^{26}$

24 ROBINSON and NUGENT, op. cit. stlpra note 19, at 265.

25 Notes appended to the sixth draft of the Uniform Small Loan Act. The draft and notes may be found in Hubachek, The Constitutronadity of SMadr LoAN Legislation (1931) App. E.

${ }^{26}$ In response to any question as to what profits the loan companies earn under such rates it should be noted that figures froin those states operating under the Uniform Small Loan Act show small loan hicensees earned an average profit of 9.4 per cent in the five years 1929-1933, the yearly figures ranging from 11.7 per cent for licensees in nine states in 1929 to 6.7 per cent for licensees in 14 states in 1933. RoBnNSON and NUGENT, op. cit. supra note 19. 


\section{RECENT EFFORTS TO SOLVE CALIFORNIA'S SMALL LOAN PROBLEM}

As the situation now stands, the basis for any system for the regulation of the small loan business must be the constitutional amendment formulated in 1933 by the legislature and ratified by the voters in $1934 .^{2 \pi}$ This amendment reduced the maximum contract rate of interest to 10 per cent per year and exempted certain classes of lenders from the operation of any usury provisions except such as the legislature might provide. ${ }^{28}$

With respect to these exempted classes legislation was adopted under which industrial loan companies' charges are limited to 6 per cent interest, deducted in advance, plus an original service charge of $\$ 2$ for each $\$ 50$ or fraction thereof $;^{29}$ credit union charges on loans to members are restricted to one per cent per month, plus insurance $\operatorname{costs}^{30}$ and licensed pawnbrokers limited to a maximum charge of 3 per cent per month on loans of less than $\$ 300$ and 2 per cent on larger loans, with a minimum charge of 50 cents per month. ${ }^{31}$ Lenders in California, therefore, fall into three definite classes: 1 . Those operating under the usury law; 2. Those whose charges are regulated by special legislation, such as pawnbrokers, credit unions, etc., and 3. Lenders exempt from operation of the usury law for whom the legislation has not as yet provided a schedule of maximum charges, such as personal property brokers.

Adoption of the Uniform Small Loan Act to govern personal property brokers was recommended in 1935 by an interim committee of the 1933 Assembly, and Assembly Bill 1618 providing for a maximum charge of $31 / 2$ per cent per month on the first $\$ 150$ of the unpaid balance and $2 \mathrm{x} / 2$ per cent on the balance up to $\$ 300$ was passed by the Assembly, but reconsideration was voted and passage finally refused six weeks later.

\footnotetext{
$2 \pi$ Supra note 13.
}

28 The exemption applied to building and loan associations, industrial loan companies, credit unions, licensed pawnbrokers, personal property brokers, banks, nonprofit co-operative associations organized under chapter 4 of division VI of the Agricultural Code ( $\$ \$ 1191-1221$ ), agencies engaged exclusively in the busimess of marketing agricultural, horticultural, viticultural, dairy, live stock, poultry and bee products on a co-operative non-profit basis which loan or advance inoney to members, or any corporation securimg money or credit from any federal intermediate credit bank which loans or advances the credit so secured.

29 Cal. Stats. 1935, p. 2055.

30 Ibid. p. 886; Cal. Stats. 1937, p. 2403.

31 Cal. Stats. 1935, p. 1613. 
In response to continued criticism of the small loan situation, however, a number of bills were introduced at the 1937 legislature. The Senate defeated Assembly Bill 63, which would have limited the maximum rate permitted personal property brokers, pawnbrokers, credit unions, industrial loan companies, banks, and building and loan associations to 10 per cent per year, and Assembly Bill 655, which sought to limit the rate for personal property brokers to 7 per cent per year. Senate Bill 33, as approved by the Senate, would have permitted personal property brokers to charge 3 per cent per month on the first $\$ 300$ of unpaid balance and $2 \mathrm{r} / 2$ per cent per inonth on the remainder up to $\$ 500$. The Assembly reduced this rate to 2 per cent per month on the first $\$ 300$ and 12 per cent per year on the balance. In conference it was agreed to allow 2 per cent per month on the unpaid balance up to $\$ 500$ and 12 per cent per year on amounts over that figure. Senate Bill 33 passed both houses in this form, but the Governor pocket-vetoed it.

\section{MEASURES BEFORE THE 1939 LEGISLATURE ${ }^{32}$}

The fifteen bills already introduced at the legislature which would affect the operations of personal property brokers and unsecured lenders fall into two distinct classes-those which would limit the return on small loans to one per cent per month and those which would combine more comprehensive regulation than is at present the case with maximum charges figuring to between 2 and $3 \mathrm{I} / 2$ per cent per month. ${ }^{33}$

All of the nine "twelve per cent per year bills" were introduced by assemblymen, and six of these proposals seek to apply the 12 per cent rate to several classes of lenders. ${ }^{34}$

32 As was cited supra, note 2, discussion in this paper is primarily limited to the problems relating to activities of personal property brokers and unsecured lenders, so bills already introduced at the legislature which bave to do with pawnbrokers, credit unions or other agencies in the small loan field will not be considered unless they also apply to either personal property brokers or unsecured lenders.

33 Only one of the 15 bills does not contain provision for a maximum charge and it, Assembly Bill 410, merely would add to the existing Personal Property Brokers Act a section (12.5) requiring dehvery to the borrower of a statement of the contract which itenizes the interest and other charges, providing for plain and complete receipts, allowing for payment in advance of the date due, and calling for cancellation and return of the note as soon as it is paid up.

34 Assembly Bills $171,386,407,408,732,2742$. These bills, though varying in detail, all seek to cover persons, associations, co-partnerships or corporations now specifically exempted by section 22 of article $\mathrm{XX}$ of the California constitution which relates to usury, and to limit the compensation including "interest" and "charges" to one per cent 
Assembly Bill 2741 pays particular attention to the problem of the unsecured lender, whose interest charges are governed by the usury law. ${ }^{35}$ Two other Assembly bills relate specifically to personal property brokers. ${ }^{36}$ These bills either limit the "compensation" embracing "interest" and the various "charges" to 12 per cent a year" or one per cent per month. ${ }^{38}$

The "Legal Aid" bills relating to personal property brokers, Assembly Bill 1192 and Senate Bill 1066, ${ }^{39}$ are patterned after the sixth draft of the Uniform Small Loan Act, and would allow a maximum charge of $31 / 2$ per cent per month on the first $\$ 100$ of unpaid balance and $21 / 2$ per cent on the balance up to $\$ 300$. Complementary to Assembly Bill 1192 and Senate Bill 1066 are Assembly Bill 1193 and Senate Bill 1125, which are intended to apply to lenders engaged "in the business of making loans of money, credit, goods or things in action, in amount or of the value of three hundred dollars" but who are not exempt from the usury law under article XX, section 22 of the California State Constitution, or in other words, the unsecured lender. These measures are patterned after the sixth draft of the Uniform Small Loan Act, and provide for a maximum interest rate of not to exceed 10 per cent per year, with the added stipulation that ". . . charges as compensation for all expenses incurred, notary fees and insurance, brokerage, services rendered, and risks assumed in connection with the said loan, which, together with the interest as hereinbefore provided, shall not exceed three and one-half per centum per month on that portion of the unpaid principal balance of any loan not in excess of one hundred dollars, or two and one-half per

a month or 12 per cent a year. Several types of regulatory devices are used, including provisions that agreements made in violation of statute are void; that violation of statute is a misdemeanor; allowance of a recovery of three times the excess "interest" and "charges" paid by any person who pays more than the law allows (Assembly Bill 171); and that all classes of lenders be under a state hicensing system (Assembly Bill 407).

35 This bill provides for a system of bensing the unsecured lender and brokers who negotiate with them for borrowers under regulations similar for the nost part to those which govern personal property hrokers and brokers who do business with them. Total "interest" and other "charges" inust not total inore than 12 per cent per annum deducted in advance.

${ }^{36}$ Assembly Bills 165 and 731 . These bills contain the cominon regulatory deviceslicensing (Assembly Bill 731) or provision that charging an excess amount is a inisdemeanor, and giving the borrower the right to recover treble the amount of compensation paid in an action instituted within a year after date of payment (Assembly Bill 165).

37 Assembly Bill 165.

38 Assembly Bill 731 .

30 These bills differ from the Uniform Act in that they provide for regulation of brokers and are silent on wage assignments. 
centum per month on any remainder of such unpaid principal balance." Lenders, under these bills, would pay an annual license of $\$ 200$ and an investigating fee of $\$ 100$.

The first small loan bill introduced in the upper house of the legislature was Senate Bill 81, which would have amended the Personal Property Brokers Act to strengthen its regulatory features and allow a maximum charge of 3 per cent per month on the first $\$ 300$ or unpaid balance and $2 \frac{1}{2}$ per cent on the balance between $\$ 300$ and $\$ 500$. Interest im the Senate, however, largely centers around Senate Bills 1066 and 1125, already mentioned, and Senate Bills 447 and 448. Companion bills to this latter pair were introduced in the lower house as Assembly Bills 1188 and $1189 .{ }^{40}$ These measures provide in general for even more stringent regulation than that of the Uniform Small Loan Act, but the inanner of setting out the schedule of charges is entirely different, and somewhat difficult to grasp on first reading. Under Assembly Bill 1189, and its companion Senate Bill 448, which relate to personal property brokers, the interest rate is set at 10 per cent per annum. In addition, however, two types of charges are provided as compensation for all expenses, services or risks assumed in connection with the investigating or servicing of such loan. ${ }^{41}$ The schedule of charges would apply on loans up to $\$ 500^{42}$ instead of a maximum of $\$ 300$ as set out in the Uniform Act. Complementary to the above are Senate Bill 447 and Assembly Bill 1188, intended to

40 These Assembly Bills (1188 and 1189), and Senate Bills 447 and 448 have the backing of the major finance companies operating in California.

41 These are: "\$ 17 (2) (i) An initial charge of seven per cent of the amount of cash advanced to or for the borrower, which shall be deemed to have been fully earned at the time the loan is made. ... Such charge shall not be contracted for, collected or received on any renewal or other loan made to the same borrower more often than once in six months; provided, however, that upon any loan made to such a borrower of a sum in excess of the amount on which such charge shall have been paid within the preceding six inonths, then such charge may be contracted for, collected and received on such excess. (ii) A monthly charge of an amount equivalent to one cent for each dollar of the balance of the amount of the loan unpaid at the time the payment is received, but not exceeding two dollars, for each successive month or major portion thereof, from the date of making the loan, that any balance of the amount of the loan remains unpaid. The loan contract shall not provide for the collection or receipt of any monthly charge prior to the last day of the monthly period in which it is earned. No such charge shall be deducted from the amount of the loan nor collected or received before the major portion of the monthly period in which it is earned has elapsed, nor shall any interest be charged or collected on such monthly charge."

42 The provision that small loan rates shall prevail on loans up to $\$ 500$ is based on the argument that a considerable portion of the finance company business in California is based on automobile loans and a $\$ 300$ linit is too low to cover this type of loan. 
apply to unsecured lenders-lenders, for purposes of the Act, being defined as all persons engaged in the business of making loans of money, credit, goods, or things in action in the amount of or of the value of $\$ 500$ or less. The regulations and system of charges are much the same as those provided by Assembly Bill 1189 and Senate Bill 448 except that the monthly charge in the unsecured lender measures is set at two cents for each dollar of the amount of the loan unpaid at the time the payment is received. The maximum such charge, however, is still $\$ 2$, the same as in Assembly Bill 1189 and Senate Bill 448.

These then are the bills already before the legislature. Just what action will be taken it is, of course, too early to predict. Much will depend on the ability of the backers of the bills which would allow a return of more than 1 per cent per month on small loans to reconcile their differences and, also, upon the voting strength of the "one per cent per month" group in the Assembly.

In the light of the fact, however, that so much attention is being given the small loan problem by both the legislature and the public, it would appear fitting that attention be called to the various constitutional questions involved in attempts to regulate lenders and brokers and to fix the interest rates and charges they collect.

PART II

CONSTITUTIONALITY OF LAWS REGULATING LENDERS, BROKERS, INTEREST RATES, AND CHARGES

In 1865 the California Supreme Court upheld the first California Usury Act, passed April 17, 1861, ${ }^{43}$ regulating the business, interest rates and charges of pawnbrokers. ${ }^{44}$ On three occasions since then, the supreme court in groups of cases considered together, has upheld usury enactments. First in 1927, when it handed down the opimions

43 Cal. Stats. 1861, p. 184, amended Cal. Stats. 1869, p. 820, Cal. Stats. 1871, p. 102, and incorporated in sections 338-343 of the Penal Code in 1872. Cal. Stats. 1881, p. 75, amended section 340 of the Penal Code by reducing the interest rate from $4 \%$ to $2 \%$ per unonth. Amended, Cal. Stats. 1929, p. 431 . By the adoption of $\$ 22$ of art. XX of the California constitution, Nov. 6, 1934, it became legal for pawnbrokers to charge whatever rate of interest they could obtain. Restrictions were again enacted by Cal. Stats. 1935, p. 1613, whereby pawnbrokers were limited as at present. See text at note 31, supra. In the earliest California case dcaling with Mexican usury law the supreme court had occasion to say that "a contract is void for usury." Fowler v. Smith (1852) 2 Cal. 568 at 570.

44 Jackson v. Shawl (1865) 29 Cal. 267. 
in the cases of Wallace v. Zinman, ${ }^{45}$ In re Washer, ${ }^{46}$ and Haines $v$. Commercial Mortgage Co., ${ }^{47}$ upholding the major aspects of the 1918 Usury Act; second in 1932, when it upheld the Personal Property Brokers $\mathrm{Act}^{48}$ with the exception of the portion permitting interest rates to be charged in excess of those allowed by the 1918 Act; ${ }^{40}$ and third in 1937, when the 1918 Act was held valid except in so far as it was repealed by the 1934 constitutional amendment. ${ }^{\text {so }}$

The justification of usury laws, often erroneously declared to be based upon history rather than justice and to be an outgrowth of the aversion of the canon law and early common law to permitting any return upon inherently unproductive money, was succinctly expressed by Justice Shaw:

"... the legislature may pass such laws as may reasonably be found necessary to protect the helpless and weak from the exactions of the strong. ... 'to protect necessity against avarice, [and] to fix such a rate of interest as will enable industry to employ with advantage a borrowed capital, and thereby to promote labor and increase national wealth'."'51

As noted before, pawnbrokers were the group of lenders first selected for regulation in California. In what appears to be the first case to reach the supreme court under this Act, the question of its constitutionality was not raised..$^{62}$ The next year, however, the Act was attacked as violative of section 11 of article I of the California Constitution of 1849 , providing that "all laws of a general nature shall have a uniform operation," because by its terms it was limited to a small number of persons. ${ }^{53}$ Without much discussion of the point, the court held "the objection made to the statute to be invalid." Substantially the same attack, made in 1885 under a similar provision in the Constitution of 1879 , was dismissed as follows:

45 (1927) 200 Cal. 585, 254 Pac. 946, 62 A. L. R. 1341. (Usury Law, Cal. Stats. 1919, p. Ixxxiii.) See Coffin, Usury in California (1928) 16 CaLIF. L. REv. 281,387.

46 (1927) 200 Cal. 598, 254 Pac. 951.

47 (1927) 200 Cal. 609, 254 Pac. 956, (1927) 205 Cal. 71, 255 Pac. 805, 53 A. L. R. 725.

48 Cal. Stats. 1909, p. 969, amended Cal. Stats. 1911, p. 978, Cal. Stats. 1931, p. 558,

Cal. Stats. 1933, pp. 814, 1496.

40 In re Halck (1932) 215 Cal. 500, 11 P. (2d) 389; Beneficial Loan Society v. Haight (1932) 215 Cal. 506, 11 P. (2d) 857.

50 Penziner v. West American Finance Co. (1937) 10 Cal. (2d) 160, 74 P. (2d) 252;

Wolf v. Pacific Southwest Discount Corp. (1937) 10 Cal. (2d) 183, 74 P. (2d) 263.

51 Ex parte Dickey (1904) 144 Cal. 234, 243, 77 Pac. 924, 928, 103 Am. St. Rep. 82,

66 L. R. A. 928.

52 Mauge v. Heringhi (1864) 26 Cal. 577.

53 Jackson v. Shawl, supra note 44, at 268.

54 Ibid. at 271 . 
"... we think the act in question may be sustained. It applies to all persons in this State engaged in the business of licensed pawnbrokers, and makes all persons engaged in that business amenable to its provisions. . . It is well known that persons frequenting the offices of pawnbrokers are generally the reckless and needy and improvident, who require tlie protection of the law. To no other class of money-lenders do the same reasons apply. Men driven by the necessities of their situation resort to the pawnbroker, and pledge any and all articles in their possession in order to raise money, and they are not particular about the rate of interest cliarged them. The pawnbroker also does a business peculiar to himself. He always requires a deposit as security for the amounts loaned, whicl are usually small, and in that respect at least, his is a business not carried on by any other person in the State. Pawnbrokers are not allowed to do a certain act because the legislature in its wisdom deemed it injurious and harmful to the community to permit them to do the prohibited act, but the like necessity for a rule of prohibition did not, in the opinion of the law-making power, apply to any other class of persons in the community."

The case has since been cited with approval by the supreme court six times. ${ }^{56}$

In Levinson v. Boas, ${ }^{57}$ decided in 1907 , the defendant was doing a general loan business, and on the side was known to the public to be receiving jewelry and diamonds, but no other class of goods, in pledge for loans. Schumacher \& Co. pledged jewelry with the defendant as security for a loan, and because the defendant was charging more than 10 per cent per annum interest, and at the same time operating without a license, the court held that the pledge agreement was void. The Act, attacked on the usual grounds, was held valid.

The second group of lenders to be recognized as a class were the personal property brokers. It was felt that the circumstances which justified the regulation of pawnbrokers were so like those that had arisen in the course of development of the personal property brokers that the latter ought also to be regnlated. The first attempts were declared unconstitutional, ${ }^{58}$ but the $1909 \mathrm{law}^{59}$ and its subsequent

55 Ex parte Lichenstein (1885) 67 Cal. 359, at 361, 7 Pac. 728, at 730, 56 Am. Rep. 713 , at 715 .

56 Ex parte Dickey, supra note 51; Ex parte Sohncke (1905) 148 Cal. 262, 263, 82 Pac. 956, 113 Am. St. Rep. 236, 2 L. R. A. (N. s.) 813 ; Levinson v. Boas (1907) 150 Cal. 185, 191; Matter of Stephan (1915) 170 Cal. 48, 148 Pac. 196, Ann. Cas. 1916E 617; Sacramento etc. Drainage Dist. v. Rector (1916) 172 Cal. 385, 390, 156 Pac. 506; In re Washer, supra note 22.

57 Supra note 56. Accord: Innes v. Goldwater (1916) 30 Cal. App. 101, 157 Pac. 18, Note (1916) 4 CALIF. L. REv. 420.

68 Ex parte Sohncke, sutpra note 46. (Act of March 20, Cal. Stats. 1905, p. 422; Act of March 21, Cal. Stats. 1905, p. 711.)

58 Cal. Stats. 1909 , p. 969. 
amendments,,$\times$ except that passed in 1931 which permitted a rate of interest in excess of that allowed by the Usury Act, ${ }^{81}$ have been sustained against every attack. ${ }^{62}$

In Ex parte Sohncke $e^{63}$ the Act of March 21, 1905 was declared unconstitutional, because

"The same acts [were] nrade punishable by different degrees of punishnient according as they [might] be coninitted by officers, servants, or employees of the corporations authorized by this particular statute, or by other persons or corporations."

The decision seems hard to justify, for it would appear that the legislature was justified in scheduling different degrees of punishment for acts in violation of the statute by the different classes, for one class was known, licensed, and paid taxes and fees, and the acts forbidden would be more easily detected when committed by this class than when performed by others.

The court seems to have been upon firmer ground in declaring invalid the Act of March 20, 1905. At that time Civil Code section 2955 listed some 22 classes of goods that might be mortgaged. The Act under review picked out of that list such items as household furniture, tools of a trade, and other items that are frequently exempt from attachment or execution, and limited the interest rate that could be charged on loans secured by such articles to $1 \mathrm{~T} / 2$ per cent per month. In view of the fact that the legislature could have declared chattel mortgages on such articles to be totally void, it would appear that in permitting them to be mortgaged, it might at the same time subject such classes to special regulation.

The foregoing are the only grounds set forth for the invalidity of those two Acts. This is of interest in view of the many other provisions found therein.

The Personal Property Brokers Act ${ }^{64}$ of 1909 was first tested in the higher courts in 1914 in the case of Eaker v. Bryant..$^{05}$ By that time the interest rate permitted had been reduced from 5 per cent per month to 2 per cent per month, but this lender had charged 3 per

60 Cal. Stats. 1911, p. 978; Cal. Stats. 1931, p. 558.

61 Matter of Stephan, supra note 56; In re Halck, stupra note 49; Eaker v. Bryant (1914) 24 Cal. App. 87, 140 Pac. 310.

62 Beneficial Loan Society v. Haight, supra note 49. See also Crooks v. Peoples Finance etc. Co. (1930) 111 Cal. App. Supp. 769, 292 Pac. 1065. See Note (1930) 18 Calrr.

L. REv. 542; (1931) 19 ibid. 213; (1932) 21 ibid. 72.

63 Supra note 56.

64 Cal. Stats. 1909 , p. 969.

65 Supra note 61. 
cent per month. After a default by the borrower, the lender proceeded to foreclose on the chattel mortgage given as security for the loan. To the defense that the transaction was forbidden by the Personal Property Brokers Act, the lender contended that the Act was unconstitutional:

"1. Because it conflicts with the requirement that all laws of a general nature shall have a uniform operation (Const. art. I, sec. 11); 2. Because it grants to some classes of citizens special privileges and immunities which upon the same terms are not granted to other citizens (Const. art. I, sec. 21); and 3. Because it conflicts with the provisions of the constitution of the United States prohibiting the various states from making or enforcing laws abridging the privileges or immunities of citizens and depriving persons of property without due process of law (U. S. Const., amdt. XIV, sec. 1)."

The court expressly passed on only the first four out of the six sections of the California law.

The precedent of Ex parte Sohncke $e^{66}$ was disposed of on the ground that the 1909 Act applied equally to all classes of personal property and to all loans on the security thereof regardless of the amount. The 1909 Act did not provide unequal punishment for similar acts, so this point could not be raised. An additional objection raised was that the Act applied only to certain lenders who were defined as personal property brokers and did not include unsecured lenders, lenders upon pledges, or lenders upon real property security. Furthermore, only personal property brokers were limited to maximum interest charges, regulations regarding giving memoranda of the loans, etc.

After quoting from Ex parte Lichenstein, the court said:

"A man engaged in the business which the statute here under review calls 'personal property broker,' also 'does a business peculiar to himself.' We find no difficulty in observing that there is a well-marked distinction between the transacting of certain business as a regular occupation and an isolated transaction of some item of business within the ordinary scope of that occupation. ... Likewise there is as much difference between the business of a personal property broker and that of one who lends money upon real estate security, as there is between the latter business and that of a pawnbroker. ... Since the legislature has not included in the prohibitions of this act those persons who make loans without security, we may reasonably assume that the legislature has not found any abuse in that business requiring public correction, if indeed it could find such business in existence at all. And since the lending of money upon the security of real estate, or of bank deposits, or of interests in estates, or of contracts, has not been included within the prohibitions of this statute, we may reasonably assume

${ }^{66}$ Supra note 56. 
that the legislature has not found that the businesses pertaining to such loans are usually accompanied by the abuses which the legislature was seeking to remedy. The exclusion from this act, of the business of taking pledges as security for loans, is accounted for by the terms of the laws already in existence, controlling the business of pawnbrokers." 67

In accordance with the provisions of the Act, the court held that the lender had no cause of action upon the note or the chattel mortgage.

The next year the Act was again upheld by the supreme court in the case of In the Matter of the Application of A. H. Stephan. ${ }^{68}$ Petitioner for habeas corpus, convicted under the Act for making a loan without giving the borrower the required memorandum, raised the same objections to the constitutionality of the Act as had been raised by the lender in Eaker v. Bryant. ${ }^{69}$ Again quoting and relying upon Ex parte Lichentein, the court upheld the Act on much the same line of reasoning as that in Eaker v. Bryant, and remanded the prisoner. ${ }^{70}$

From 1909 to 1931 the Personal Property Brokers Act remained unchanged, except when in 1911, the rate was reduced from 5 per cent per month to 2 per cent per month. ${ }^{71}$ The 1931 revision, ${ }^{72}$ however, was thorough-going, and incorporated into the Act many of the recommendations of the Russell Sage Foundation. ${ }^{73}$ The rate, for instance, was raised to $3 \mathrm{~T} / 2$ per cent per month on the unpaid balances on loans up to and including $\$ 300$; all personal property brokers were required to apply for and obtain a license, post a $\$ 5000$ bond, and give evidence of "financial responsibility, experience, character and general fitness"; the license was non-transferable, had to be posted conspicuously in the place of business and any change of address could be made only upon notice to the commissioner; the commissioner of corporations was given power to examine the books of the licensees, to charge the examinee at certain rates therefor, and to revoke the licenses for cause. Finally the commissioner was given

67 Eaker v. Bryant, supra note 61, at 92,140 Pac. at 312.

c8 Supra note 56.

69 Supra note 61.

70 The act by section four made contracts and security agreements void if they exceeded the legal rate of $2 \%$, while by section six it provided that lenders who failed to give the borrower a memorandum of the agreement as prescribd by section five would be punishable by a fine. The court held that a violation of section five did not void the contract, but simply made the guilty lender subject to fine. Wood v. Krepps (1914) 168 Cal. 382, 143 Pac. 691, L. R. A. 1915B 851; cf. Innes v. Goldwater, supra note 57. 71 Cal. Stats. 1911, p. 978.

72 Cal. Stats. 1931, p. 558.

73 Supra note 8. See HubacheK, op. cit. supra note 23 ; HuBAcHeK, op. cit. supra note 25 . 
authority to compel the licensees to keep books in compliance with the provisions of the Act and to establish other rules deemed "reasonable or necessary for the execution of the provisions" of the Act. Only section 1 , defining a personal property broker, section 5 requiring that a memorandum be delivered to the borrower, and section 6 , affecting the punishments, remained unchanged.

The supreme court disposed of the attack on this 1931 Act in two well considered opinions, In re Halck ${ }^{74}$ and Beneficial Loan Society, Ltd. v. Haight. ${ }^{75}$. Halck, a personal property broker lending sums in excess of $\$ 300$ upon security, was convicted of a violation of the Act because he failed to take out the license required by section 7 . Arguing that the new provision of the Act, section 7 through 16 summarized in the preceding paragraph, were unconstitutional, he sought release through habeas corpus proceedings. The court considered the main points seriatim. The title of the Act was held sufficient. The commissioner's authority was held to be neither arbitrary nor capricious because he was authorized to deny licenses to those without "financial responsibility, experience, character and general fitness."

Upholding the stringent regulations the court said: ${ }^{77}$

"Personal property brokers seem generally to be the subject of rather severe regulation in practically every jurisdiction of the country; the policy also seems to be, as here, to require this class of our citizens to defray the expense of this regulation."

To the charges that the Act was discriminatory and was not uniform in its operation in that brokers making loans of $\$ 300$ or less were permitted to charge $31 / 2$ per cent per month whereas those who loaned on larger sums alone were denied this privilege, being held to the 12 per cent per annum rate, the court said: ${ }^{78}$

". . . petitioner is uninjured, for he may elect without restraint or additional outlay to come under the favored provisions by extending his business to cover loans of $\$ 300$ or less. The act purports to regulate all classes of brokers on the same terms and conditions and any member of either class may at will, and without burden, join the other. The smaller loan broker may be favored, but, if so, it is not at the expense or to the injury of the larger class. The hicense fee is not the price of the privilege to charge the

74 Supra note 49.

75 Ibid.

70 In re Halck, supra note 49 , at 504, 11 P. (2d) at 391.

77 Ibid. at 504, 11 P. (2d) at 392. Cal. Stats. 1931, p. 558: "Such applicant ... shall pay ... (\$100) as a fee for investigating the application, and ... (\$250) as an annual license fee, ..." There are other examination fees, restrictions and regulations.

78 Ibid. at 505, 11 P. (2d) at 392. 
three and one-half per cent interest rate; this privilege is sought to be founded upon economic reasons."

In Beneficial Loan Society, Ltd. v. Haight ${ }^{70}$ decided the same day, it was held that the license provisions of the Act were valid and that the corporation commissioner must issue a license to duly qualified applicants even though the section permitting interest charges in excess of 12 per cent per annum was void, as being in conflict with the 1918 Usury Law. Although the court felt compelled to hold these sections invalid, it expressly stated that the Usury Law did not prevent a classification of brokers according to the amount involved and the nature of the security taken; nor a statute allowing the legal rate fixed by the Usury Law, but limiting the service or expense charges to the actual outlay, and not to exceed a definite limit.

From the foregoing it would seem reasonable to summarize the law as follows: (1) Personal property brokers are a class sufficiently recognized to be susceptible of special legislation; (2) Except as rates are controlled by the first two paragraphs of the 1934 amendment, the legislature may (a) permit one rate of interest upon loans under certain fixed amounts and another upon loans over said amounts; and (b) may discriminate between secured and unsecured lenders; and (c) where reasonable restrict the time period of loans; (3) The legislature may require persons going into the business to obtain licenses, post bonds, pay fees, and file reports giving such information as the commissioner considers relevant, and (4) It may delegate supervisory powers to proper authorities, such as the corporation commissioner, and in doing so give him power to examine the books of licensees and others carrying on such a business, charge the expenses therof to such examinees, revoke licenses, and establish such rules and regulations as he may deem reasonable or necessary.

The early case of Ex parte Sohncke $e^{80}$ may be deemed to be law today, as applied to personal property brokers, in only two respects: (1) the legislature must not discriminate between lenders who take chattel mortgages upon one kind of personal property and lenders who take mortgages upon another kind where there is no legitimate reason for the distinction, and (2) the same acts must not be made pumishable by different degrees of punishment according as they may be committed by officers, servants, or employees of the corporations authorized by the particular statute, or by other persons or corporations. 
In 1933, following the Beneficial Loan Society case declaring the rate structure of the Personal Property Brokers Act invalid, the legislature passed a new Act. ${ }^{81}$ The most significant change was that all rules as to interest rates were eliminated. The second primcipal change was that the broker who negotiated the loan on behalf of the borrower was brought under the Act, compelled to obtain a license, and subjected to the supervisory functions of the corporation commissioner. However, the Act did nothing to regulate the fees of brokers, which have always been without legal limit in California. The commissioner's power was enlarged to permit him to suspend or amend as well as to revoke licenses, and to require all forms used by licensees to be submitted to him for his approval prior to use thereof. His acts and rulings were made subject to review by the courts. A new schedule of punishments for the violation of the several sections of the Act was adopted. None of these new provisions have as yet been passed upon by the courts, but the questions raised thereby will be discussed later.

The effect of the 1934 constitutional amendment, ${ }^{82}$ exempting certain classes of lenders from all usury laws except such as the legislature should subsequently pass, was to relieve personal property brokers of all restrictions as to rates. ${ }^{83}$ Thus the solution of the problem of personal property brokers, as well as that of other businesses constitutionally classified, ${ }^{84}$ is now clearly within the province of the legislature. Not subject to such comparatively simple solution, however, are the problems to which the remainder of this article is devoted: that of the unsecured lender, still subject to the constitutional maximum of 10 per cent interest; and that of the intermediary nonlending brokers, subject at present to no adequate regulation.

Investigation of complaints made to the offices of district attorneys and the Legal Aid workers often discloses that the unsecured

81 Cal. Stats. 1933, pp. 814, 1496.

82 CaI. Const. (1934) art. XX, \& 22.

83 Matulich v. Marlo Investment Co. (1936) 7 Cal. (2d) 374, 60 P. (2d) 842; Penziner v. West American Finance Co., supra note 50. All causes of action under the usury law not reduced to final judginent against personal property brokers were held to be extinguished by the amendinent. Wolf v. Pacific Southwest Discount Corp., supra note 50 .

81 The other classes of lenders named in the aunendment as exempt were recognized as being subject to special legislation even before they were classified in the constitution. These are: huilding and loan associations, industrial loan companies, credit unions, banks, nonprofit cooperative associations organized under chapter 4 of division VI of the Agricultural Code, nonprofit cooperative marketing associations, corporations, partnerships lending money to their own members, and federal intermediate credit banks. 
lender has kept within the 10 per cent per year maximum, but that the intermediary, a broker, charged the borrower his fee, and that it was this fee which made the total cost to the borrower mount to 250 per cent or even as much as 500 per cent of the loan. The broker who negotiates the loan is the agent of the borrower and may charge his principal such fees as he will. ${ }^{85}$ Any small loan law that fails to control and regulate the broker, therefore, will prove utterly worthless.

As was mentioned earlier in this article, considerable expense is involved in making small loans. Under the old California maximum of 12 per cent interest, the small loan business could not be conducted profitably; hence the lenders shifted as much of their expenses as was possible onto the brokers who were entirely free from regulation. Large eastern lending firms entered the state but did business only through brokers. The brokerage system created in those years is still used by the unsecured lenders and it is this situation which must be inet by the legislature.

Large lenders frankly state that they neither like nor approve of the brokerage system and that if they were permitted to charge high enough rates they would drive the brokers out of business. To make this possible, of course, the charges would have to be considerably higher than one per cent per month. Even if it were $31 / 2$ per cent per month the resulting maximum would cornpare favorably with the current system of charges running 200 per cent and even greater in many cases.

Since the legislature is powerless to permit unsecured lenders to charge more than 10 per cent interest per year, few legislative solutions are possible. The definition of a personal property broker might be changed to include the unsecured lender; the unsecured lender might be permitted to make express charges to cover necessary expenses; or the brokerage system might be continued but subjected to regulation. The first proposal is unlikely to meet with favor because of the danger of such action being declared unconstitutional. Possibly the only practical solution is to combine the second and third choices by providing that the total charges of interest and expense of both lender and broker, when added together shall not exceed the lawful maximum rate. This is provided for in the Legal Aid Bills. ${ }^{80}$

85 Niles v. Kavanagh (1918) 179 Cal. 98, 175 Pac. 462, 1 A. L. R. 831 ; Herzer v. Lee (1920) 46 Cal. App. 582, 189 Pac. 493; Vaughan v. People's Mortgage Co. (1933) 130 Cal. App. 632, 20 P. (2d) 335; Wallace v. Zinman (1927) 200 Cal. 585, 254 Pac. 946, 62 A. L. R. 1341.

86 Supra note 39. The first proposal is not untenable, however, for the classification "personal property broker" is not qualified nor restricted by reference to statute as are 
This raises two questions: First, may the legislature constitutionally permit a lender to make extra charges; and second, may the legislature constitutionally limit the fees and charges of lenders and brokers?

First, California's Usury $\mathrm{Law}^{8 \tau}$ when enacted provided in sections 1 and 2 the maximum "interest" rates, and in section 3, the maximum permissible other charges, fees, commissions and bonuses, thus clearly indicating that under the law interest and other charges were not always identical, nor did "interest" include always "other charges."

The actual meaning of this section was not clear, and was never clarified by judicial decision. In holding those portions of section 3 which permitted but controlled additional charges unconstitutional the court declared that: (1) A lender must not charge or receive more than the then permissible 12 per cent per annum as interest; nor is he to be allowed by any subterfuge, form of agreement or otherwise to evade this limit; ${ }^{88}$ but that (2) he is permitted to charge the borrower, and collect from him, his necessary expenditures incurred in the making of the loan, as long as none of these payments go to the pockets of the lender. ${ }^{80}$

The 1931 legislature accordingly amended section 2 of the Personal Property Brokers Act" to provide that the lender "may charge, receive and collect a benefit or percentage upon money or other thing advanced, or for the use and forbearance thereof, of three and onehalf per centum per month on remaining unpaid balances on sums loaned up to and including the sum of three hundred dollars. ..." In section 3 it provided:

"No further or other charges either for recording, insuring or examining the security or property, or for the drawing, executing or filing of papers, or for any services or upon any pretext whatsoever beyond the aforesaid

the other constitutional classifications, and has been construed elsewhere to include the unsecured lender. CAL. Const. art XX, $\$ 22$.

87 Supra note 45 .

88 Wallace v. Zinman, supra note 85 , at 597, 254 Pac. at 951 . Accord: Terry Trading Corp. v. Barsky (1930) 210 Cal. 428, 292 Pac. 474; Connor v. Minier (1930) 109 Cal. App. 770, 288 Pac. 23 ; Penziner v. West American Finance Co. (1933) 133 Cal. App. 578.

80 Wallace v. Zinınan, supra note 85, at 590, 254 Pac. at 948 . See Haines v. Commercial Mortgage Co. (1927) 200 Cal. 69, 254 Pac. 956; Niles v. Kavanagh; Herzer v. Lee; Vaughan v. People's Mortgage Co., all supra note 85. Cf. Miley Petroleum Corporation, Ltd. v. Amerada Petroleum Corp. (1936) 18 Cal. App. (2d) 182, 63 P. (2d) 1210. The Federal Courts are in accord. Low v. Sutherlin, Barry \& Co. (C. C. A. 9th, 1929) 35 F. (2d) 443. See Hugill, Protection Afforded the Borrover by the California Usury Law-An Interpretation of Recent Cases (1932) 20 CALIF. L. REv. 361.

${ }^{30}$ Cal. Stats. 1931, p. 558. 
charge for interest or discount shall be asked, charged, or in any way received, where the same would thereby make a greater charge for the money or thing advanced than the aforesaid rate and where made, all such charges shall be considered and be of the same effect as so much added interest."

The court held these amendments invalid, ${ }^{01}$ on the ground that they.permitted a lender to.charge up, to $31 / 2$ per cent per month whether or not the additional actual expenditures added to the interest would total that amount; hence the Act permitted a lender to charge more than 12 per cent interest per annum and conflicted with the Usury Law. The court, however, expressly declared:02

"Nor are we intending to hold that a statute which allows the legal rate fixed by the Usury Law and yet himits the service or expense charges to the actual outlay, and not to exceed a definite limit, would be in conflict with other provisions of the Usury Act. The Usury Law does not purport to fix or limit the legitimate expense or service charge that may properly be borne by the borrower."

It therefore seems safe to conclude that the legislature may enact a law permitting a lender to make charges to cover service and expense outlays, and charge for the same in addition to the lawful interest, and at the same time to provide that such service and expense charges shall not exceed a named limit.

The final problem remains. May the legislature regulate the business of independent intermediary brokerage, of those not lenders themselves nor connected with the lenders, but legally the agents of the borrowers?

As society becomes more complex, professions more technical and population more dense, we find the courts upholding the subjection of more and more businesses and callings to regulatory and supervisory legislation. The fact situation touched upon at the beginning of this article and known to every Legal Aid Society and relief agency in the state shows a combination of circumstances, peculiar to the loan brokerage business, in which the regulative force of competition has so failed to function that borrowers in small sums are definitely and substantially placed at a disadvantage in their bargaining. The legislature may reasonably anticipate serious consequences to the community as a whole unless it steps in to fix the prices that may be charged for the broker's services. ${ }^{03}$

91 Beneficial Loan Society, Ltd. v. Haight, supra note 49.

02 Ibid. at 517,11 P. (2d) at 861 .

93 Scudder v. Hoyt (1927) 245 N. Y. 522, 157 N. E. 842. 
The facts demonstrate that a broker does "a business peculiar to himself." He deals with a great body of our population which is susceptible to imposition and deception. He deals with a necessitous class, men and women without resources and in desperate need of money immediately. Borrowers are under moral, family and economic compulsion to take the loan on the terms demanded. The business is subject to grave abuses, involving frauds and impositions upon a peculiarly helpless class. It particularly attracts the unscrupulous and designing.

Of the many abuses in the business perhaps the worst lies in the brokerage fee charged the borrowers. The broker needs no capital, he lends the money of another; he easily draws customers by advertisements in the daily press, and the borrowers frequently must act in haste because of an emergency. The borrower does not learn until later of the experiences of others, for borrowers are embarrassed by the feeling that they are dealing with a "loan shark" and tend not to tell others of their difficulties; thus competition is almost non-existent. That which follows may not be extortion, but it has as serious a result on the borrower, his family and his legitimate creditors. While it would be unwise legislation to fix a fee limit so small as to drive the fair and legitimate broker out of business, it is nevertheless clear that the public interest can only be safeguarded by the enactment of legislation fixing reasonable limits. Either laws must limit brokers' fees or the public interest will not be safeguarded. When a remedy is required and fee regulation is the only remedy that is effective, the legislature has power to regulate those fees.

Robert E. Stone.

SCHOOL OF JURISPRUDENCE,

UNIVERSITY OF CAIIFORNIA.

Jack E. Thomas.

Untversity of California.

\section{APPENDIX \\ COMPARISON OF THE UNIFORM SMALI LOAN ACT WITH THE CALIFORNIA PERSONAT PROPERTY BROKERS ACT}

At the present writing it is uncertain what course the legislature will pursue in regard to the small loan problem in Cahfornia. However, it would seem that future legislation would be hest framed hy using the Uniform Small Loan Act as the basis, because (a) many of the bills now pending are based substantially on the Uniform Act, (b) there is great need for uniformity in state laws, and the U.S.I.A. has already been enacted in more than half of the states, (c) twenty-one of the twenty-seven sec- 
tions of the Uniform Act are practically the same as the present California law, and (d) California lawyers will be enabled to benefit by the case interpretation of the Uniform Act by the courts of other states, and California annotations may be practically and quickly developed.

To this end a comparison of the U.S. L.A. and the California Personal Property Brokers Act is here presented,* dealimg first with the respects in which the two are alike, and second, with those respects in which they differ.

\section{Respects in Which the Two Acts are Similar}

First it is to be noted that the two Acts have, in general, the same objective: the regulation of the busimess of lending small sums and to that end requiring such lenders to be licensed, bonded, and subjected to rules promulgated by the Commissioner.

In addition, the following requirements are common to both Acts: The application for a license must be under oath and in the form prescribed by the Commissioner, $[U . \S 2-C . \S \S 5,6]$ and must be accompanied by a $\$ 1000$ bond, to be approved by the Commissioner, and running both to the state and to any persons who may have a cause of action against the obligor under the provisions of the Act. [U. \$3-C. \$7].

If the application and bond are approved and requisite fees paid, the Commissioner shall issue a license to make loans at the location specified in the application, provided that, upon investigation, he shall find that the applicant is financially responsible, and has such experience, character, and general fitness as to convince the Commissioner that the business will be operated honestly, fairly, and efficiently. [U. §4—C. \$8].

The license shall state the name of the licensec and the address at which the business is to be conducted. [U. \$5-C. \$8]. It must be kept conspicuously posted in the place of business. No licensee shall transact its business under any other name or at any other place of business. [U. §7-C. §12]. Though only one place of business shall be maintained under each license, the Commissioner may issue branch licenses upon comphance with the provisions of the law. Licenses shall not be transferable nor assignable [U. §5-C. §10], and license fees must be paid annually. [U. §8-C. §8].

The Commissioner shall, upon notice to the licensee and after hearing, revoke any license, if he shall find that the licensee has failed to obey any of the provisions of the Act or the rules of the Commissioner. [U. \$9-C. \$14]. Licenses may be suspended. [U. \$9-C. \$14]. Revocation or suspension of licenses and all other acts of the Commissioner are subject to judicial review. [U. \$g-C. \$15].

In order to secure information lawfully required by him, the Commissioner may at any time order an investigation of the loans and businesses of the lender, whether such lender is operating under or without authority of the Act. The examiners shall have free access to the offices, books, vaults, etc. of the examinees, and the authority to require the attendance of witnesses and to examine them under oath. An exarnination is required at least once each year. [U. \$10-C. \$16]. The Commissioner may collect the cost of the examination from the licensee. [U. \$10-C. \$17].

The licensee shall keep such records as will enable the Commissioner to enforce the Act and must preserve all books and documents for at least two years after making the final entry on any loan recorded therein. [U. \$11-C. \$18]. The Commissioner may check the advertising of the license. [U. $\$ 12-\mathrm{C} . \S 13(\mathrm{~B})]$. Both Acts make it a misdemeanor to engage in the busmess without a license, or at an unlicensed location. These penalties can be incurred by the several members, officers, directors, agents and/or employees of lenders. [U. \$19-C. \$21]. Neither Act applies to state or national banks, building and loan associations, credit unions, or licensed pawnbrokers. [U.\$20-C.\$4(a)]. The Commissioner is to establish rules and regulations for the execution of the provisions of the Act. [U. \$21-C. \$19]. Each Act contains a provision that if any part of the Act be declared unconstitutional, the rest remains valid. [U. \$26-C. \$24].

Respects in Which the U.S. L.A. Would Change the Present California Law

The adoption of the U.S.L.A. would bring both secured and unsecured lenders under one act, and fix the maximum rate, which must include all charges, fees, broker's charges, etc. [U. \$13]. The 1934 constitutional amendment probably makes it impos-

"Throughout this Appendix the Uniform Small Loan Act is indicated by the symbol "U." and the California Personal Property Brokers Act by a "C." 
sible to bring the secured and unsecured lender under the same law. Finally it would substitute a maximum rate of $3 \mathrm{t} / 2$ per cent per month in lieu of the unlimited amounts now permitted. Any contract violative of the Act is void. [U. \$13]. This is a most radical departure from the California law. The U.S.L.A. unakes it a misdemeanor even to contract for usurious interest. Loans in excess of $\$ 300$ are forbidden, except at the rate permitted unlicensed lenders. [U. $\$ \$ 13,15]$. Non-licensees are prohibited from exceeding the statutory rate. [U. \$18]. In California this would be 10 per cent.

The license fees schedules vary but little. Under the U.S. L.A. there is an application fee of $\$ 50.00$ plus the annual license fee of $\$ 100$ [U. \$2], and the examinee must pay the cost of examinations. [U. \$10]. At present, in California, \$100 includes both application fee and license fee for the first year [C. \$20], and the Commissioner may charge the cost of examination to the lender. [C.\$17]. Additional fees for eacli branch are different. [U. \$7-C. \$20].

The U.S. L. A. requires as conditions precedent to the granting of a license that the loan office will promote the advantage of the community in which it is located and that the applicant lias at least $\$ 25,000$ in liquid assets available for use in the business. [U. $\$ 4]$. There are no sucl requirements in the California law.

In regard to bond requirements the California law may conflict with the U.S.L. A. The latter definitely permits the Commissioner, at any time that the bond posted is insecure, to require an additional $\$ 1000$ bond to be filed within ten days. [U. \$6]. But the California Act states: "Every personal property broker and every broker, at the time of filing such application, shall deposit with the commissioner and thereafter maintain a bond ... in the aggregate sum of $\$ 1,000 \ldots$ The total aggregate liability, however, on said bond shall be limited to the payment of one thousand dollars." [C. \$7]. The meaning of that part of the section containing the phrase "and thereafter maintain" would be clear but for the apparently contradictory last sentence, whicl would seem to mean that the total liability of both principal and sureties is limited to $\$ 1000$ and that when a bond is depleted in part, that thereafter no greater liability exists than the balance of the bond. However, it would be possible to interpret the section to mean that the total liability on any one bond shall be $\$ 1000$, but that as fast as one bond is inpaired or exhausted the lender must provide another.

Under the California law, suspension requires notice and an opportunity for hearing, but under the U.S.L.A. the Commissioner may, witlout notice or liearing, suspend any license for a period not exceeding thirty days, pending investigation. [U. \$9-C. \$14].

Under the Uniform Act licensees must file annual reports, of whicl the Commissioner is to make and publish an annual analysis and recapitulation. [U. §11]. The data so obtained proves valuable to the legislature in passing subsequent regulatory acts. The licensee must not conduct lis business in any place in which any other business is solicited or engaged in, except as may be authorized $\mathrm{m}$ writing by the Commissioner. $[U, \S 12]$. Nor shall the licensee take any confession of judgment or power of attorney. [U. §12].

The licensee must give the borrower, when the loan is made, a statement containing in full the usury provisions of the Act, the terms and maturity dates of the loan, and the nature of the security, if any, and complete receipts specifying how the payment was applied and the amount still due; permit payments to be made im advance; upon final payment mark all obligations "paid" or "cancelled", and release and return mortgages, pledges and notes; and display in his place of business the full schedule of charges. [U. §14].

Under the California Labor Code valid wage assignments are limited to cases where wages have been earned, or where they are made to persons furnishing necessities, and even then they must be signed by the spouse, if the assignor is married. [CAI. LABOR CODE $\$ \$ 300-304]$. Since money lenders do not furnisl necessities, the only wage assignments upon which they can lend are those for wages then past due. The Uniform Act would change the foregoing slightly, as follows:

1. It validates assignments for other than necessities, thereby permitting lenders to legally take future wage assignments. [U. $\$ \$ 16,17]$.

2. No more than 10 per cent of the laborer's wages shall be collectible from the employer by the licensee at the time of each payment to the borrower of such wages. 
[U. 817]. This is of slight legal benefit to the lender, but is always a threat which a lender could employ with ignorant employees to their great disadvantage.

3. The Act provides that the difference between the amount actually paid the borrower at the time of the assignment and the amount of the wages assigned shall be deemed interest or charges.

The assignment portions of the Uniform Act might with advantage be omitted in California, since Califorma's present legislation is probably superior. [CAL. LABOR CodE $\$ \$ 300-304]$.

The Uniform Sinall Loan Act covers inany of the detailed problems of loan regulation: For instance, the data that must be incorporated in tbe application for a license is expressly prescribed. [U. \$2]. The Commissioner must pass on applications within 60 days. [U. \$4]. The Act states that a license may be revoked or suspended for but one location, or that the order may apply to all. [U. \$9]. The obligations which may not be avoided by a surrender of a license are listed. [U. §9]. The Commissioner has power to reinstate a license upon condition. [U. \$9]. While the California Act implies that loans must be made upon personal property [C. $\$ 2(2)]$, the U.S.L.A. prohibits taking liens upon real estate, except such lien as is created by law upon the recording of a judgment. [U. \$12]. Rules re maintenance of bond and capital [U. \$6], form and method of giving notice [U. §7], form and contents of notes [U.\$12], and other relations between lender and borrower, are helpfully explicit.

A most interesting addition to the accumulating standard clauses now being cunployed in legislative drafting is one to prevent the vesting of privileges under an Act so that they may not be modified by subsequent enactments. It reads as follows: "This Act or any part thereof may be modified, amended, or repealed so as to effect a cancellaation or alteration of any license or right of a licensee hereunder, provided that such cancellation or alteration shall not impair or affect the obligation of any pre-existing lawful contract between any hicensee and any borrower." [U. \$22].

\section{Portions of the Personal Property Brokers Act Which will Cease to be Operative as Law if the Uniform Small Loan Act is Adopted}

The "broker", who serves as agent of the borrower, for a compensation, and is distinguished from the personal property broker, the lender, will not be under bond, license or other regulation, and there is a possibility he will be eliminated. This is because the lender will (a) not be permitted to have a broker operate in connection with him and in his place of business, and (b) because the lender's charges must include all fees. [C. \$2U. $\$ \$ 12,13]$. But since the brokerage system has become so entrenched in California, legislation should be retained and strengthened to control the condition should it survive.

The California law states that as used therein, "conditional contracts of sale" shall include flooring contracts. [C. \$3]. The Uniform Trust Receipts Act has been passed since the date of the last amendment of the Personal Property Brokers Act, so it is doubtful if this inclusion serves any useful purpose. [CAY. CIv. CoDE $\$ \$ 3012-3016.16]$.

By express exclusion, the Act does not apply to bona fide conditional contracts of sale of personal property [C. $4(\mathrm{c})]$, but probably the same result is obtained in the U.S. L.A. by the language expressly limiting its operation to loans. [U. $\$ \$ 1,13,18]$.

The California law contains some provisions a few of which might well have been included in the U.S.I.A. For instance, the former provides: "The commissioner may, from time to time, annend or alter, either upon bis own motion or upon application of the licensee without any fee therefor any license theretofore issued by lim." [C. \$11]. Again: "The commissioner may issue duplicate licenses. ..." [C. \$12]. Also the California law requires all licensees to submit sample copies of written instruments utilized by them to the Commissioner and first obtain his approval thereof prior to their use by the licensees. [C. $\$ 13(\mathrm{a})$ ]. It further provides that the Commissioner may require any licensee to submit and secure [the] approval of all advertising. [C. $\$ 13(\mathrm{~b})]$. The burden of proof lies upon tbe appellant in proceeding for judicial review, and tbe court is limited to a consideration and determination of the question whether there lias been an abuse of discretion on the part of the Commissioner in making an order, decision, finding, requirement or rule. [C. \$15]. 